\title{
The Motivation to Become A Seniorpreneur: Spiritual Motivation
}

Marlina Muhamad, Mohd Fazil Jamaludin, Mohd Firdaus Ruslan, Fariza Hanis Abd Razak \& Haryani Haron

To Link this Article: http://dx.doi.org/10.6007/IJARBSS/v11-i5/9921

DOI:10.6007/IJARBSS/v11-i5/9921

Received: 01 March 2021, Revised: 30 March 2021, Accepted: 23 April 2021

Published Online: 15 May 2021

In-Text Citation: (Muhamad et al., 2021)

To Cite this Article: Muhamad, M., Jamaludin, M. F., Ruslan, M. F., Razak, F. H. A., \& Haron, H. (2021). The Motivation to Become A Seniorpreneur: Spiritual Motivation. International Journal of Academic Research in Business and Social Sciences, 11(5), 244-253.

Copyright: (c) 2021 The Author(s)

Published by Human Resource Management Academic Research Society (www.hrmars.com)

This article is published under the Creative Commons Attribution (CC BY 4.0) license. Anyone may reproduce, distribute, translate and create derivative works of this article (for both commercial and non-commercial purposes), subject to full attribution to the original publication and authors. The full terms of this license may be seen

at: http://creativecommons.org/licences/by/4.0/legalcode

Vol. 11, No. 5, 2021, Pg. 244 - 253

Full Terms \& Conditions of access and use can be found at http://hrmars.com/index.php/pages/detail/publication-ethics 


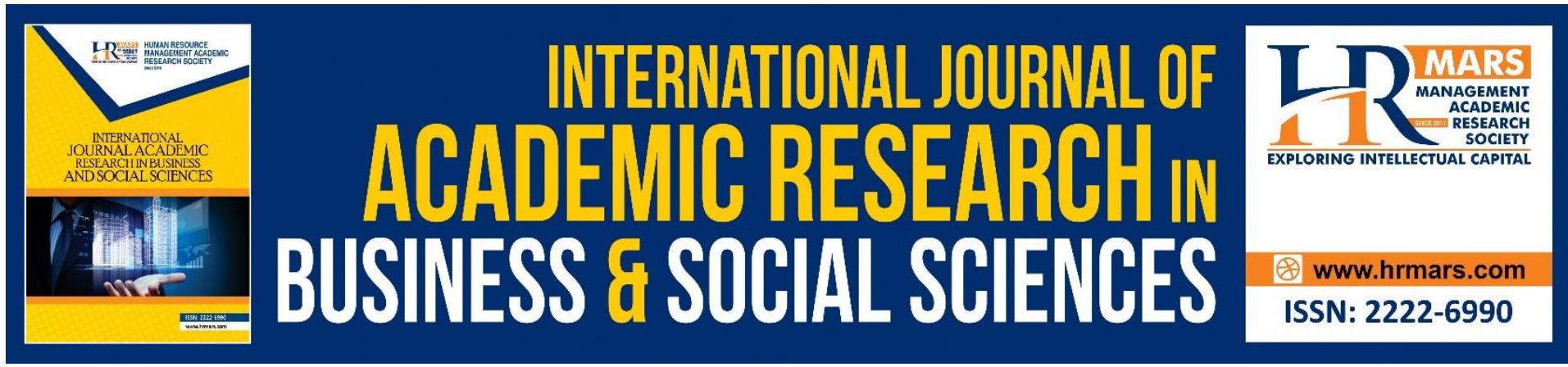

\title{
The Motivation to Become A Seniorpreneur: Spiritual Motivation
}

\author{
Marlina Muhamad, Mohd Fazil Jamaludin, Mohd Firdaus \\ Ruslan, Fariza Hanis Abd Razak \& Haryani Haron \\ Universiti Teknologi MARA, Shah Alam, Malaysia \\ Email: marlina326@uitm.edu.my
}

\begin{abstract}
This qualitative study aims to contribute by exploring the existing theory on push and pull motivations within the entrepreneurial event model to see what is missing from the existing researche. This study uses semi-structured, face-to-face interviews with a total of six Malaysian seniorpreneurs for data collection. Content analysis method was used to extract their motivation from the qualitative data. The results reveal that in terms of theoretical, spiritual motivation is one of the motivations in driving seniorpreneurs to do business apart from push and pull motivations. The findings from this study may expand a research area of practical applications of spiritual motivation in the business environment which still empirically is not sufficiently covered.
\end{abstract}

Keywords: Seniorpreneur, Entrepreneurship, Push Motivation, Pull Motivation, Spiritual Motivation

\section{Introduction}

People have various motivations to be an entrepreneur, including elderly who becoming seniorpreneur after retirement age. Since researches on the seniorpreneur phenomenon are relatively new, this cohort are not excluded from the primary theory development around entrepreneurial motivations which has been categorized as push and pull motivations (Shapero \& Sokol, 1982). According to (Gabarret \& Vedel, 2015), the periods in between pre and post retirement, that use a psychological approach, is a phase where elderly are motivated by factors either intrinsic or extrinsic to start business. Volume of entrepreneurship studies, motivation factors was classified either push or pull (Hakim, 1989). In the creation of new business, motivation shows an essential part and becomes an underpinning theory. Herron \& Sapienza (1982) stated, there are not incomplete theories of business creation to address this notion. More recently, (Gimmon et al., 2018) reported that the motivation of elderly in becoming a seniorpreneur, are differ from young entrepreneurs, thus, seniorpreneur's entrepreneurial motivation leave some spaces to be explored and require further research. This was supported by (Kean et al., 1993; Maalaoui et al., 2013), that not many studies have focused on seniorpreneur motivations.

Seniorpreneurs have been found to be motivated by intriguing push and pull factors that drive them to pursue entrepreneurship (Ahmad et al., 2014). Push factors related in 
doing entrepreneurship due to necessity and negative factors as the motivation such as unemployment, fewer jobs available, or insufficient money (Biron \& St-Jean, 2018). The second factors, pull, related in doing entrepreneurship based on favourable circumstances (opportunity) identified and usually positive factors as the motivation such as just for emancipation, self-achievement, prosperity, and other attractive outcomes (Segal et al., 2006; Ahmad et al., 2014). Classic psychological theory best explained the differentiation between push and pull motivation based on intrinsic and extrinsic drives (Ryan \& Deci, 2000; Carsrud \& Brannback, 2011; Gimmon et al., 2018). Carsrud \& Brannback (2011) added, the willingness to do something because it seems interesting is associated with intrinsic motivation while extrinsic motivation refers in doing something that can guarantee a reward that follows certain behavior.

People who are driven by intrinsic motivation, do something that are valuable for them for meaningful purpose and give commitment to achieve their goals that could satisfy themselves, however people extrinsically motivated, are forced to do something for financial purposes or internally such as guilt and for wealth (Gimmon et al., 2018). Kean et al., (1993) highlighted that the main catalyst for starting a business may not always be the motive for monetary value and financial reliefs. Ryan \& Deci (2000) added people are healthier and happier each day when their purposes are more intrinsically motivated. Ferssizidis et al., (2010) found that better life satisfaction and influence by positivity factors were related to intrinsically motivating social values, whereas negative effects related to being forced to commit to extrinsically motivating values such as do it for the monetary purpose. Similar to other entrepreneurs, seniorpeneurs are also likely to satisfy either extrinsic or intrinsic needs (Kean et al., 1993). Intrinsic is differ from extrinsic motivation where Solymossy (1997) suggests that individuals can be motivated by intrinsic factors without any forces, following the pull theories while the contradicting view associates to negative situational factors (extrinsic factors) can derive in some elderly are forced to jump into entrepreneurship.

According to McLelland Theory of Achievement, pull factors encompass deliberations for the need of achievement McLelland (1961) whereby push factors include limited job available (Gimmon et al., 2018). The link between seniorpreneurs' intentions and actions can be best explained by both motivations (Gimmon et al., 2018). Age moderates a variety of aspects when it comes to the entrepreneurial behaviour, thus entrepreneurial motivation among elderly are slightly different (Levesque \& Minniti, 2006; Lewis et al., 2006).

Retirement is one of the aspects of aging, which nowadays are considered as a shift rather than the old definition used previously in which a person is an employee today and retired the next day. Han \& Moen (1999), defined with this view of retirement as a process instead of retiring forever, reported only around half of elderly entering the retirement age forever. Balance of the remainder, some elderly choose partial retirement in which they continue to work part-time, while others retire at first and then return back to work, essentially "unretiring" (Seltzer et al., 2013). With the increasing number of elderly people worldwide by the increase in longevity and decrease in economic security, gerontologists began to fluctuate their attention from elderly dependence to productive ageing which emphasizes of elderly continue to make contributions through entrepreneurship (Sun, 2013; Gimmon et al., 2018).

Based on motivation theories as discussed above, Gimmon et al., (2018) reported after retirement, since elderly have more spare time and less formal responsibilities, perhaps long before they actually become entrepreneurially involved they already realize their goals and objectives and Gimmon et al., (2018) also added that there are differences of seniorpreneurs' 
motivation toward entrepreneurship in comparison to younger age cohort. Gimmon et al., (2018) continues, elderly people, who have ambition as entrepreneur during their early stages of life and could not implement it earlier are more driven by the willingness to fulfil their longhad ambitions and achievement for self-fulfilment. However, elderly can also be motivated by specific push motivations other than financial purposes that are more towards keeping them occupied and surrounded by their 'elderly environment' such as to be in a circle of family and friends. This is an extrinsic motivation type based on the need to get connected and attention from friends and families that is usually associated with changing from pre and post retirement to do and see things that may motivate elderly to go into business (Gimmon et al., 2018).

\section{Method}

In this study, a qualitative research method has been applied by researchers since the aim of this research is to build in depth understanding of motivation to become a seniorpreneur. To learn about the issue from participants and involve in the best practices to dig in information is the key element for qualitative research (John, 2007). The contribution to both theoretical as well as empirical can be implemented through qualitative research (Mayrhofer et al., 2004). Researchers conducted semi-structured interviews from one individual to another, face-to-face basis with six participants by visiting their business residents who become seniorpreneurs after retirement age. The interviews took place until data saturation developed in their responses. According to Jennings (2011), reaching to the saturation stage determines the point at which adequate data have been generated, accordingly, the sufficient number of participants to be involved. The sample size for qualitative research is often small (Fossey et al., 2002; Ryan et al., 2007). They were identified through purposive sampling by selecting participants who represent the seniorpreneurs running their own business and had started entrepreneurial activities right after retirement age by being involved in the entrepreneurial activities. Purposive sampling is the main technique in qualitative research because researchers choose the most appropriate participants that are able to answer research questions (Marshall, 1996).

To extract more on their motivations to start a business at later age, the participants were probed to stretch out details on what motivated them to do business after retirement at later age. Particularly, reasons they preferred to have their own business were also asked from participants. Table 1 presented the details of the participants including their demographic.

Although this study participants came from different educational backgrounds, the conclusion is that they are homogeneous participants as all of them are seniorpreneurs after they retired from their former employment and there was not included any seniorpreneurs before retirement age.

The validity of a qualitative research should be heed by the researcher (Maxwell, 1992). To ensure the research findings validity, steps were taken in a credible scholarly manner. There are some strategies to promote qualitative research validity as suggested by Johnson (1997). Two strategies have been used to promote the findings in this study which are Low Inference Descriptor and Data Triangulation. The presentation of participants views by using quotations from the participants' answers is described as the low inference descriptor. Johnson (1997) mentioned "a verbatim is the lowest inference descriptor of all because the participants' exact words are provided in direct quotation." Furthermore, John (2007) highlighted that the researcher in qualitative research should bring in the voice of 
participants in the study by using many quotes. By conducting multi-interview in different times and places with different people, this research was defined as a data triangulation method (Johnson, 1997).

TABLE 1 : Table of Participants

\begin{tabular}{|c|c|c|c|c|c|c|c|c|}
\hline $\begin{array}{l}\text { Participa } \\
\text { nt }\end{array}$ & $\begin{array}{l}\text { Gend } \\
\text { er }\end{array}$ & $\begin{array}{l}\text { Age } \\
(202 \\
0)\end{array}$ & $\begin{array}{l}\text { Educatio } \\
\mathrm{n}\end{array}$ & $\begin{array}{l}\text { Previous } \\
\text { Employme } \\
\text { nt }\end{array}$ & $\begin{array}{l}\text { Nature of } \\
\text { Business }\end{array}$ & $\begin{array}{l}\text { Busine } \\
\text { ss Age } \\
\text { (year) }\end{array}$ & $\begin{array}{l}\text { Relate } \\
\text { d } \\
\text { Industr } \\
y\end{array}$ & $\begin{array}{l}\text { Age at } \\
\text { Start- } \\
\text { up } \\
\text { Busine } \\
\text { ss }\end{array}$ \\
\hline P1 & $M$ & 62 & PhD & $\begin{array}{c}\text { Academici } \\
\text { an }\end{array}$ & $\begin{array}{l}\text { Materials } \\
\text { and } \\
\text { Automoti } \\
\text { ve }\end{array}$ & 2 & Yes & 61 \\
\hline P2 & $\mathrm{F}$ & 61 & SPM & Clerk & Laundry & 3 & No & 57 \\
\hline P3 & $M$ & 57 & SPM & $\begin{array}{c}\text { Manager } \\
\text { (Hospitalit } \\
\text { y) }\end{array}$ & $\begin{array}{c}\text { Homesta } \\
y\end{array}$ & 3 & No & 54 \\
\hline P4 & $\mathrm{F}$ & 55 & Degree & Teacher & Pet Shop & 4 & No & 51 \\
\hline P5 & $\mathrm{F}$ & 65 & STPM & Teacher & $F \& B$ & 7 & No & 58 \\
\hline P6 & $\mathrm{M}$ & 60 & Degree & Manager & Laundry & 1 & No & 60 \\
\hline
\end{tabular}

\section{Results and Discussion}

The qualitative analysis from the six series of interviews with seniorpreneurs at their business property have been analysed through thematic analysis in three themes. There are namely 'push' motivations in doing seniorpreneurship, 'pull' motivations in doing seniorpreneurship, and spiritual motivations in doing seniorpreneurship. To be sustainable in any new business, motivations play an important aspect and themes related to the seniorpreneurs' motivations were dug from the transcription.

\section{Pull Motivations in Doing Seniorpreneurship}

Two of the participants mentioned they become seniorpreneur specifically to fulfil their longhad dreams while they were still working previously. They are eager to be an entrepreneur while they are still healthy, and they want to maintain their healthy lifestyle. This is related to pull motivation because they are not pushed to do entrepreneurship. It is more of their choices. For their pleasure. For example, P1 who retired at the age of 60 (compulsory retirement age in Malaysia), indicated that he wanted to use his 30 years of skills in automotive and parts of his hobbies as well to opened-up a workshop for vehicles that can give advantage to people nearby. $\mathrm{P} 1$ explained:

"I decided to start this workshop because I have knowledge previously while working as a lecturer in a private university in Malaysia and my education background is aligned with this business (Automotive Engineering). And because of the connection I have with my relatives, I can get cheap tires. Because of the cheap price I get (my relatives get the cheap price from the main supplier, also known as the source), I can offer a relatively cheap price to my customer compared to other workshops. I really wanted to become an entrepreneur because of my passion. I am passionate about what I am doing. This is always my ambition to open up 
a 24-hours workshop. I have six old cars at home, and I like to fix them. It is my hobby. All that activities at my workshop keep me healthy because I sweat all over my body and by the time I'm home, I'd be in deep sleep. I consider it as my physical workout each day."

Similarly, P4 who started a pet shop business said:

"I decided to open a pet shop long before I retired. 2 years before I opt for retirement (optional retirement age at 51 years old), I already started this business. I wanted to do what I really like to do since I believed I am capable of running a pet shop. Besides my passion as a cat owner and cat lover, I am always hungry for information and knowledge related to cats. Cats are my medical therapy and cats make me feel healthy and energetic."

\section{Push Motivations in Doing Seniorpreneurship}

Other than pull motivations, two participants mentioned that they were pushed to start a business at a later age due to few factors such as to generate income for their family, to become the first generation of entrepreneur in the family so that they can pass the business to their children, and insecure financial stability. For example, P2 said:

"I wanted to do business because I wanted to add on the source of income apart from monthly pension. At the beginning, I bought this traditional laundry shop from my friend because I thought I could pass this business to one of my children since she's not working and not highly educated."

Similarly, P6 who owned a self-service laundry shop indicated:

"The main thing I can see from doing a business is I can generate more money. I didn't get the chance while I was young since I'm working for others, but now after I retired, I use my EPF (employee provident fund) as financial capital to set up a self-service laundry shop to generate more income for me and my family. As you know, I do not have a monthly pension like other people who retired from the government sector. So, I need to do something so that every month I have income to pay all the bills and as a breadwinner by ensuring towards the end of a month, everything is sufficient."

\section{Spiritual Motivations in Doing Seniorpreneurship}

Out of six, four participants exhibit their motivations in doing business are linked with the spiritual belief. For Muslims, spirituality is a belief as the connection of relationship with solely God. The individual's behaviors determine their fundamental purpose of life is linked to Islamic spirituality (Grine et al., 2015). Four participants commented that financial purpose is not the main motivator in doing business. The need to give back to communities by providing jobs, to customers by providing cheaper price, to paying 'zakat pendapatan' (income tax in Islam) and to follow Prophet (SAW) customs and practices as their main motivational in doing business. P1 explained:

"I wanted to help people by providing them job and I paid my workers a salary that I believed was above market compared to other workshops. I provided them with meals every day because I believed it is a charity and when they are happy, they can give back their loyalty and their enthusiasm to this workshop. Some good days, I give them tips and provide my 
employees with incentives of punctuality. Usually I do not express my anger to my workers. I treat them nicely. If the spare parts are accidentally broken, it is beyond their control. I would say that my tolerance level is quite high. I am not easily upset with people. When my customer comes, usually I talk with them, ask them whether they would like to drink and ask them about the service. Sometimes, if there's extra meals, I will invite my customer to eat while waiting for their car. I considered myself fully dependent on my Creator (God). Every day I never know how many customers I can get and what types of services the customer wanted. The most important is charity. Next is Dhuha prayer. Dhuha is done as a form of charity. And what suffices for that (as a charity) are the two rak'as of Dhuha. I believed that praying Dhuha gives a reward of charity due from every joint in the body from that day. I managed to open this workshop and this strategic location with the cheaper rent all are from my Creator."

Similarly, P2 commented:

"Everyone who does business wants a profit, but that's not the main motivation because my children are all grown up and I only have 2 children and a husband (small family). So, the responsibility regarding financial matters are not too much. Quite minimal. Basically, I rely on 'rezeqi' (sustenance). If I have more, then I'll be very grateful, but if not too much, I still be grateful."

P3 added:

"I also motivated to do business, because according to Prophet (SAW) trading or business was obviously the preferred way to make a living. The Holy Prophet (SAW) has said: There are 10 parts of earning, out of which 9 parts are in business. Also, when I rent out my homestay, I prepared prayer mat, Qiblat, Quran, so at least, when people come in, they pray I also can be rewarded with 'pahala'."

P5 also added:

"I believe I can do good deeds when I do this business. In a way, I helped people with this business. I provide food and drinks when people need to find a nearby restaurant, especially those who do not have time to cook at home. At the beginning, I offered a lunch buffet for a very cheap price where my customers could eat almost anything from the tables. They bring their children and family members since my restaurant is the only one offered this type of meal."

In summary, the discussions of the motivations to become seniorpreneurs not only centered on the push and pull motivations, however the spiritual motivation appeared to be one of a strong belief in doing seniorpreneurship activities. As Muslim entrepreneurs, the satisfaction from doing a business derives strong Islamic beliefs and hence they become motivated (Adamu et al., 2011). According to Ahmad (2011), the whole set of Islamic practices revolve around the existence of intention. The person with sincerity is motivated in doing entrepreneurship with the greatest purpose of searching the contentment from God rather than other ambiguous purposes such as seeking for wealth, fame, and name (Ahmad, 2011).

Ahmad (2011) emphasized in order to reap more in the hereafter, the performance of an entrepreneur (guided by spirituality) who is guided by his entrepreneurial activities as one of the religious activities and who believe in getting reward in the hereafter can be maximized. 
In addition, Ali (2005) asserted Islamic spirituality helps in maintaining self-confidence and assurance during the difficult times and struggle, as sometimes faced by many entrepreneurs.

According to Ali (2005), the trajectory of religiosity is not always similar for every individual, with the likelihood of the level of religiosity varying with changes in age. As people grow older, their level of spirituality also grows. And all these are usually true for Muslims as it is for those of other faiths. For example, any religious institutions are mostly attended by older people.

TABLE 2 : Classification of seniorpreneurs' motivations.

\begin{tabular}{|c|c|c|c|}
\hline Drivers & Pull factors & Push factors & Spiritual factors \\
\hline $\begin{array}{l}\text { Motivatio } \\
\text { ns }\end{array}$ & $\begin{array}{l}\text { - Personal interest } \\
\text { - Fulfilling a dream } \\
\text { - Self fulfilment } \\
\text { - Meaningful } \\
\text { activity }\end{array}$ & $\begin{array}{l}\text { - Economic needs } \\
\text { - Financial instability } \\
\text { - To become first } \\
\text { generation } \\
\text { entrepreneur }\end{array}$ & $\begin{array}{l}\text { - To get rewarded with } \\
\text { 'pahala' } \\
\text { - To do charity } \\
\text { - To follow Prophet } \\
\text { (SAW) practices }\end{array}$ \\
\hline
\end{tabular}

\section{Conclusion}

In conclusion, to identify what is missing from the existing researches in term of seniorpreneurs' motivation in doing business after retirement age become the objective of this study. There are growing numbers of studies on exploring spirituality among young entrepreneurs however, it was remained unknown regarding seniorpreneurs motivation in doing business due to low number and insufficient studies conducted since this subject is relatively new especially in developing countries. This study has identified spiritual motivations as one of the motives among seniorpreneurs to start and to sustain their business. As known, older adults' level of spirituality is greater than any other age group. Spirituality provides significant motivation to business start-up. Through spirituality, business is expanding and improving. The findings from this research will be of interest in senior entrepreneurship field as this study moves to practical applications of spirituality concept into the business environment which strengthen their determination as seniorpreneurs.

\section{Acknowledgements}

Researchers gratefully acknowledge UiTM Kedah Branch for funding this research under the Excellence Fund and thank the reviewers, for their careful reading of the manuscript and their many insightful comments and suggestions.

\section{References}

Adamu, I. M., Kedah, Z., \& Osman-Gani, A. A. (2011). Entrepreneurial motivation, performance and commitment to social responsibility: a conceptual analysis on the influence of Islamic religiosity. 10th International Conference on the Academy of HRD (Asia Chapter).

Ahmad, M., \& Khan, S. (2015). A Model of Spirituality for Ageing Muslims. Journal of Religion and Health.

Ahmad, N. H., Nasurdin, A. M., Halim, H. A., \& Taghizadeh, S. K. (2014). The Pursuit of Entrepreneurial Initiatives at the "Silver" Age: From the Lens of Malaysian Silver Entrepreneurs. Procedia - Social and Behavioral Sciences, vol. 129, pp. 305-313. https://doi.org/10.1016/j.sbspro.2014.03.681, 2014. 
Ahmad, S. (2011). Introjecting core Islamic values for raising the employee's behaviour. In K. Ahmed, R. Islam, \& Y. Ismail (Eds.), Issues in Islamic Management, pp. 342- 354, IIUP press.

Ali, A. J. (2005). Islamic perspective on management and organization. Edward Elgar Publishing Limited.

Biron, D., \& St-Jean, E. (2018). A Scoping Study of Entrepreneurship Among Seniors: Overview of the Literature and Avenues for Future Research. Handbook of Research on Elderly Entrepreneurship, pp. 17-41.

Carsrud, A., \& Brannback, M. (2011). Entrepreneurial motivations: what do we still need to know? Journal of Small Business Management, vol. 39 (1), pp. 9-26.

Ferssizidis, P., Adams, L. M., Kashdan, T. B., Plummer, C., Mishra, A., \& Ciarrochi, J. (2010). Motivation for and commitment to social values: the roles of age and gender. Motivation and Emotion, vol. 34 (4), pp. 354-362.

Fossey, E., Harvey, C., McDermott, F., \& Davidson, L. (2002). Understanding and Evaluating Qualitative Research. Australian and New Zealand. Journal of Psychiatry, 36(6), 717732.

Gabarret, I., \& Vedel, B. (2015). For a new approach to entrepreneurial motivation. The Journal of Management Sciences, pp. 13-20.

Gimmon, E., Yitshaki, R., \& Hantman, S. (2018). Entrepreneurship in the third age: retirees' motivations and intentions. International Journal Entrepreneurship and Small Business, vol. 34 (3), pp. 267-286.

Grine, F., Fares, D., \& Meguellati, A. (2015). Islamic Spirituality and Entrepreneurship: A Case Study of Women Entrepreneurs in Malaysia. Journal of Happiness \& Well-Being, vol. 3 (1), pp. 41-56.

Hakim, C. (1989). New recruits to self-employment in the 1980s. Employment Gazette, pp. 286-297.

Han, S. K., \& Moen, P. (1999). Clocking Out: Temporal Patterning of Retirement. American Journal of Sociology, vol. 105 (1), pp. 191-236.

Herron, L., \& Sapienza, H. J. (1992). The entrepreneur and the initiation of new venture launch activities. Entrepreneurship Theory and Practice, vol. 17 (1), pp. 49-55.

Jennings, B. J. (2011). Factors that Contribute to Knowledge Sharing Within Research Based Organizations. The University of New Mexico. ProQuest Dissertations and Theses. 219. Retrievedfrom:http://search.proquest.com.ezaccess.library.uitm.edu.my/docview/89 4470951? accountid=42518. (894470951).

John, W. C. (2007). Qualitative Inquiry and Research Design: Choosing Among Five Approaches. SAGE Publications.

Johnson, R. B. (1997). Examining the Validity Structure of Qualitative Research. Education, 118(2), 282-292.

Kean, R. C., Van Zandt, S., \& Maupin, W. (1993). Successful aging: the older entrepreneur. Journal of Women \& Ageing, vol. 5 (1), pp. 25-42.

Levasque, M., \& Minniti, M. (2006). The effect of aging on entrepreneurial behaviour. Journal of Business Venturing, vol. 21 (2), pp. 177-194.

Lewis, K. V., \& Walker, E. A. (2013). Third age self-employment: a business assistance perspective. Journal of Small Business and Enterprise Development, vol. 20 (2), pp. 399419. 
Maalaoui, A., Castellano, S., Safraou, I., \& Bourguiba, M. (2013). An exploratory study of seniorpreneurs: a new model of entrepreneurship intentions in the French context. International Journal of Entrepreneurship and Small Business, vol. 20 (2), pp. 148-164.

Marshall, M. N. (1996). Sampling for Qualitative Research. FamilyPractice, 13(6), 522-526.

McClelland, D. C. (1961). The achieving society. Princeton, NJ: Princeton University Press.

Maxwell, J. A. (1992). Understanding and Validity in Qualitative Research. Harvard Educational Review, 62(3), 279-301.ISO 690.

Mayrhofer, W., Meyer, M., Steyrer, J., Maier, J., Langer, K., \& Hermann, A. (2004). International Career Habitus-Thick Descriptions and Theoretical Reflections. In Academy of Management Annual Meeting Symposium on Global Careers and Human Resource Development: Emerging IHRM Perspectives New Orleans, USA. ISO 690 .

Ryan, F., Coughlan, M., \& Cronin, P. (2007). Step-by-step Guide to Critiquing Research. Part 2: Qualitative Research. British Journal of Nursing, vol. 16(12), pp. 738-744.

Ryan, R. M., \& Deci, E. L. (2000). Intrinsic and extrinsic motivations: classic definitions and new directions. Contemporary Educational Psychology, vol. 25 (1), pp. 54-67.

Segal, G., Borgia, D., \& Schoenfeld, J. (2006). The motivation to become an entrepreneur. International Journal of Entrepreneurial Behaviour \& Research, vol. 11 (1), pp. 42-57.

Seltzer, J. A., Yahirun, J. J., \& Bianchi, S. M. (2013). Co-residence and Geographic Proximity of Mothers and Adult Children in Stepfamilies. Journal of Marriage and Family, vol. 75(5), pp. 64-80.

Shapero, A., \& Sokol, L. (1982). The social dimensions of entrepreneurship. Encyclopaedia of Entrepreneurship, pp. 72-90.

Solymossy, E. (1997). Push/pull motivation: does it matter in terms of venture performance?," in Reynolds, P.D., Bygrave, W.D., Carter, N.M., Davidsson, P., Mason, C.M. and McDougall, P.P. (Eds.): Frontiers in Entrepreneurship Research, pp. 204-217, Babson College, Boston, MA.

Sun, J. (2013). Chinese Older Adults Taking Care of Grandchildren: Practices and Policies for Productive Aging. Ageing International, vol. 38, pp. 58-70. 